\section{Assessment of the Soil Vulnerability Index and comparison with AnnAGNPS in two Lower Mississippi River Basin watersheds}

\author{
L.M.W. Yasarer, S. Lohani, R.L. Bingner, M.A. Locke, C. Baffaut, and A.L. Thompson
}

\begin{abstract}
There is an increasing need to quickly and accurately identify areas where agricultural conservation practices can provide the greatest reduction in nutrient and sediment runoff. Geographic information systems (GIS)-based tools and indices are promising for identifying critical areas that are significant contributors of nonpoint source pollution loads with limited data. One such tool, the Soil Vulnerability Index (SVI), is tested here in Beasley Lake and Goodwin Creek watersheds in Mississippi. The SVI runoff component results are compared against aerial images and long-term land use histories in the watershed to determine if a higher SVI score is related to visibly degraded land or land removed from cultivation. SVI results are also compared to sediment yield estimates generated with the Annualized Agricultural Non-Point Source pollution model (AnnAGNPS) to determine the degree of agreement. The SVI runoff score demonstrated agreement with imagery and land use histories in both watersheds. The SVI categories and corresponding AnnAGNPS-predicted sediment yield also had moderate agreement, with $45 \%$ and $68 \%$ of watershed area in agreement in Beasley Lake and Goodwin Creek watersheds, respectively. In general, the tool is a quick way to assess spatial areas potentially contributing to nonpoint source pollution, which can then be combined with field-based knowledge and/or imagery to provide valuable insight for placement of conservation practices.
\end{abstract}

Key words: AnnAGNPS—conservation targeting-Mississippi-sediment yield-Soil Vulnerability Index-SVI

\begin{abstract}
Managing agricultural landscapes to reduce nonpoint source runoff and pollution remains a global challenge, with widespread understanding that there is not a one-size-fits-all approach to solve nutrient or sediment problems. However, one of the first steps in any approach to target conservation practices is often to evaluate where nutrient or sediment loads are highest. There are numerous tools for identifying critical areas, including a suite of watershed and field-scale models and indices that have been developed for this purpose; each requires various inputs and degrees of user expertise (Tim et al. 1992; Niraula et al. 2013). Models, such as the Agricultural Policy Environmental eXtender (APEX), the Soil and Water Assessment Tool (SWAT), and the Annualized Agricultural Non-Point Source (AnnAGNPS) pollution model, have been used to identify critical areas within
\end{abstract}

Universal Soil Loss Equation (RUSLE2) for estimating long-term average annual soil loss (Foster et al. 2001), the Phosphorus Index (PI) for assessment of phosphorus (P) movement risk (Gburek et al. 2000), and the Soil Management Assessment Framework (SMAF) for evaluating impacts of management on soil quality or health (Andrews et al. 2004). Whether a tool is simple or complex, generally the goal for conservation planning is to identify hydrologically sensitive areas (HSAs; areas prone to generating runoff) and critical source areas (CSAs; areas where pollutant loading overlaps with a HAS) where conservation efforts would have the greatest impact (Agnew et al. 2006).

The Soil Vulnerability Index (SVI) is a GIS-based tool that identifies hydrologically sensitive areas, as well as areas sensitive to leaching. The SVI was developed by the USDA Natural Resources Conservation Service (NRCS) to assess areas vulnerable to runoff-induced sediment and nutrient losses, and leaching of nutrients in percolation and subsurface flows (Chan et al. 2016; Lee et al. 2018). This tool relies on simple and widely available inputs, such as soil parameters and slope, and thus can be utilized quickly for most watersheds in the United States (Chan et al. 2016). The SVI was developed using the APEX model in the Upper Mississippi, Ohio, and Tennessee River basins (Chan et al. 2016). More detailed information on the development of the SVI can be found in Chan et al. (2016) and several papers in this special issue.

As the SVI was developed using simulations in the northeastern and midwestern United States, it is critical to expand performance assessment in other regions and climates. In particular, the Lower Mississippi River Basin (LMRB) has some of the high-

Lindsey M.W. Yasarer is a research hydrologist at the National Sedimentation Laboratory, USDA Agricultural Research Service (ARS), Oxford, Mississippi. Sapana Lohani is a postdoctoral researcher at the University of Nevada-Reno in the Department of Biology, Reno, Nevada. Ron L. Bingner is an agricultural engineer and Martin A. Locke is a soil scientist and laboratory director at the National Sedimentation Laboratory, USDA ARS, Oxford, Mississippi. Claire Baffaut is a research hydrologist in the Cropping Systems and Water Quality Research Unit, USDA ARS, Columbia, Missouri. Allen L. Thompson is a professor in the Department of Bioengineering, University of Missouri, Columbia, Missouri. 
est rainfall intensities in the United States. Rainfall is one of the critical factors for simulating runoff and associated pollutant loads in watershed models; however, rainfall amount and intensity are not included in the SVI. Therefore, two watersheds located within Mississippi in the LMRB were used in this study to assess the SVI and compare to watershed results that incorporate the impacts of precipitation. The Beasley Lake (BL) watershed and Goodwin Creek (GC) watershed have been studied under the Conservation Effects Assessment Project (CEAP). Both watersheds have high average annual rainfall $\left(1,330 \mathrm{~mm} \mathrm{y}^{-1}\right.$ and 1,358 $\mathrm{mm} \mathrm{y}^{-1}$, respectively) and soils prone to high runoff. The SVI results were assessed in three ways: (1) SVI results were compared to aerial imagery to assess if visual degradation matched with high SVI results; (2) SVI results were compared to land use histories in the respective watersheds to evaluate the SVI category for land retired from crop production; and (3) SVI results were compared to sediment yield predictions from runoff-validated AnnAGNPS simulations to assess the degree of agreement between the SVI tool and a more complex watershed model. This study contributes to a wider effort to evaluate the suitability of the SVI to identify critical source areas for nonpoint source pollution in watersheds across the United States (Chan et al. 2016).

\section{Materials and Methods}

Study Area. The GC and BL watersheds are both located in Mississippi within the LMRB and are a part of the USDA ARS CEAP Watershed Assessment Study (CEAP WAS). The GC watershed is approximately 2,132 ha, located in the bluff hills region of Panola County in north central Mississippi. The GC watershed and bluff hill region are characterized by a patchwork of cropland, pasture, forest, and urban land uses with varying slope, erodible soil prone to gullying, and intense rainfall. More than half of the GC watershed has a slope greater than $6 \%$, and $15 \%$ of the watershed has a slope less than $2 \%$. Average rainfall is $1,358 \mathrm{~mm} \mathrm{y}^{-1}$. In the early 1980 s, cultivated land covered $26 \%$ of the watershed, but this has declined to less than 6\% since 2004 (Kuhnle et al. 2008; Dabney et al. 2012). Forest/timber and pasture/idle land are the majority of the land use types in the watershed. Cropland historically was planted with cotton (Gossypium hirsutum
L.) and more recently soybean (Glycine max [L.] Merr.). Upland soils in the GC watershed are defined by a thin layer of loess, while cultivation is most common in the alluvium soils along the streambank; estimated watershed sediment loads are $13.2 \mathrm{t}^{\text {ha }} \mathrm{y}^{-1}$ (Kuhnle et al. 2008). Soil series found in the watershed include Calloway, Collins, Falaya, Grenada, Loring, Memphis, and Ruston. Soil hydrologic group $\mathrm{D}$ is most common in the watershed (53\%), with groups B (21\%) and C $(26 \%)$ representing the remaining watershed. Gullied soils did not have an assigned hydrologic soil group or K-factor in the Soil Survey Geographic (SSURGO) database; these soils were assumed to have hydrologic group C and a K-factor of 0.49 (Seth Dabney, personal communication, May 20, 2016).

Beasley Lake is a small 625 ha oxbow lake watershed located in Sunflower County, Mississippi, next to the Sunflower River $\left(33^{\circ} 24^{\prime} 15^{\prime \prime} \mathrm{N}, 90^{\circ} 40^{\prime} 05^{\prime \prime} \mathrm{W}\right)$. The BL watershed and surrounding area are part of the Lower Mississippi Alluvial Plain (i.e., the Delta), and are characterized by intensive row crop agriculture, flat slopes, and intense rainfall. About $89 \%$ of the $\mathrm{BL}$ watershed has a slope less than $4 \%$, and annual rainfall is $1,330 \mathrm{~mm} \mathrm{y}^{-1}$. The main land uses in the watershed include 140 ha of forest/ riparian wetland, 85 ha of Conservation Reserve Program (CRP) land, and 270 ha row cropland, which was historically cotton, but has been planted in a soybean rotation from 2002 to present (Locke et al. 2008; Lizotte et al. 2017). All runoff within the watershed flows into the lake via drainage ditches, and the lake contains an outlet pipe that drains into the Sunflower River. Soil texture ranges from sandy loam to clay, and organic carbon (C) is typically less than $2 \%$. Soils are primarily hydrologic soil group D $(66 \%)$ and $\mathrm{C}(31 \%)$, with a small proportion of soil group B (3\%). Dominant soil series include Alligator, Bosket, Dowling, Dundee, Forestdale, and Sharkey.

While these two watersheds are both located in the LMRB and both experience similar average rainfall, they vary in several key ways (table 1). The first obvious difference is watershed size, with GC more than three times the size of BL. Second, the watershed topography is quite different between the sites, which can be seen in the dominant slope categories and the difference in watershed shape (figure 1). In terms of soil, both watersheds have soils with high K-factors and high runoff potential; however, BL watershed soils contain more clay, while GC watershed soils are mostly silt loam. Agricultural management practices also differ, with the GC watershed representing upland Mississippi land use practices, such as dryland farming and a mix of pasture, forest, and row crops, and the $\mathrm{BL}$ watershed representing conditions common in the Mississippi Delta, such as predominantly row crop farming with furrow irrigation and land-leveling.

AnnAGNPS Model Setup. The AnnAGNPS model was developed to evaluate the effectiveness of conservation practices and assist conservationists in identifying critical areas contributing to nonpoint source pollution (Bosch et al. 1998). The model is designed to simulate long-term average conditions, and can be used in ungauged watersheds. Runoff is estimated using the modified Soil Conservation Service curve number $(\mathrm{CN})$ method, while sheet and rill erosion are estimated with RUSLE (Renard et al.1997). The RUSLE model is also used to simulate land cover and management conditions. The Hydro-geomorphic Universal Soil Loss Equation (HUSLE) estimates sediment delivery, and the Bagnold equation estimates sediment transport capacity (Bagnold 1966; Theurer and Clarke 1991). In this study, we are utilizing AnnAGNPS to estimate edgeof-field sediment yield; therefore, these are the most pertinent aspects of the model to discuss here. A more extensive description of AnnAGNPS and its capabilities can be found in Bingner et al. (2015). Because AnnAGNPS and RUSLE have both been utilized by state and national agricultural conservation agencies for natural resource planning in the past, there is a need to compare AnnAGNPS results to those generated by the SVI to assess the degree of agreement in identifying areas of high vulnerability.

A detailed description of the GC simulation development and streamflow validation can be found in Yasarer et al. (2018). Streamflow was validated at the monthly time step from 1982 to 1991. Measured data were obtained from four stations: three upstream stations and one station at the outlet. Model performance was assessed using the NashSutcliffe Efficiency (NSE) and percentage bias (PBIAS) (Moriasi et al. 2015). Simulated monthly runoff had excellent agreement with observed values at three subwatersheds and the watershed outlet with NSE values ranging from 0.91 to 0.94 and PBIAS between 


\section{Table 1}

Characteristics of Beasley Lake and Goodwin Creek watersheds.

\begin{tabular}{|c|c|c|}
\hline Characteristics & Beasley Lake watershed & Goodwin Creek watershed \\
\hline Size (ha) & 625 & 2,132 \\
\hline Average annual rainfall (mm) & 1,330 & 1,358 \\
\hline Dominant soil types & $\begin{array}{l}\text { Alligator, Bosket, Dowling, } \\
\text { Dundee, Forestdale, } \\
\text { and Sharkey }\end{array}$ & $\begin{array}{l}\text { Calloway, Collins, Falaya, } \\
\text { Grenada, Loring, Memphis, } \\
\text { and Ruston }\end{array}$ \\
\hline $\begin{array}{l}\text { Area historically in row crop } \\
\text { production (ha) }\end{array}$ & $451(1995)$ & $745(1937)$ \\
\hline $\begin{array}{l}\text { Area currently in row crop } \\
\text { production (ha) }\end{array}$ & 337 & 147 \\
\hline
\end{tabular}

\section{Figure 1}

Location of Beasley Lake (BL) and Goodwin Creek (GC) watersheds in Mississippi; hydrologic soil group distribution in GC (top) and BL (bottom) watersheds.

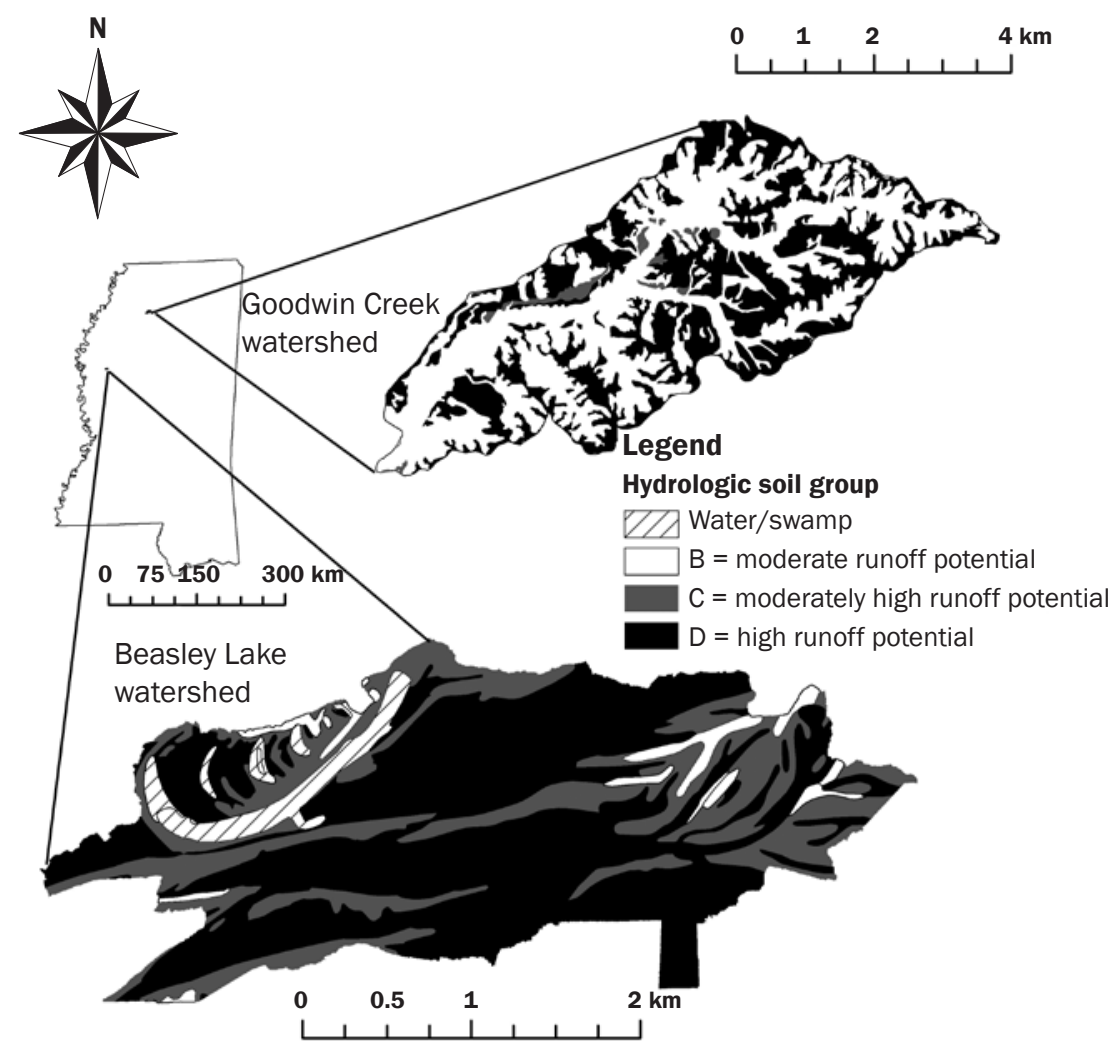

years of simulated weather data to initialize and stabilize internal variables and 21 years of observed weather to generate average sediment yield values. The number of years for simulation was constrained by the availability of quality assured rain gauge records from within the watershed, as 17 stations were used to represent the spatial heterogeneity in rainfall patterns.

The streamflow-validated BL model simulation utilized $1.5 \mathrm{~m}$ resolution hydrologically corrected Light Detection and Ranging (LiDAR) digital elevation model (DEM), SSURGO soils (Soil Survey Staff 2018a, 2018b), and management practices based on 15 years of management records collected in the watershed. Climate data were collected from a hybrid of sources, including a nearby long-term weather station in Moorhead, Mississippi (about 11 miles from the watershed), from 1970 to 1999, and from a Soil Climate Analysis Network (SCAN) climate station located within the watershed with data available from 2000 to 2014 (NOAA 2017; USDA NRCS 2017). The runoff was validated from 2000 to 2002 at two in-field monitoring locations, BL1 and BL3, which were maintained by the US Geological Survey (USGS 2010). Event-based NSE and PBIAS values of 0.70 and $1.43 \%$ for location BL3, and 0.51 and $-5.3 \%$ for location BL1 were determined. Land management within the watershed was simplified to represent bedded and disked soybeans with no conservation practices. The simulation was run with 3 years of weather data to initialize and stabilize internal variables and 44 years of observed weather to generate average sediment yield values. General information on the AnnAGNPS framework for both simulations can be found in table 2 .

SVI Assessment. The SVI soil runoff risk classification utilized input layers for soil hydrologic group and RUSLE soil erodibility (K-factor) derived from the NRCS-SSURGO database (Soil Survey Staff 2018a, 2018b) and percentage slope based on LiDAR-derived DEMs. Both GC and BL watersheds had LiDAR-derived DEMs available with resolution of $1 \mathrm{~m}$ and $1.5 \mathrm{~m}$, respectively. The SVI classification created from the LiDAR-derived DEM was utilized in the historical comparison portion of this analysis. The SVI was also reassessed using the spatial scale defined by the AnnAGNPS cells in both BL and GC watersheds to compare directly to AnnAGNPS
Wilson et al. 2014). As the focus of the current study was edge-of-field sediment yield, in-stream concentrations would not be comparable. The streamflow-validated simulation was developed using observed land management from 1982 to 1991. In the present study, land management on agricultural area was simplified to represent soybeans, which are the most common crop currently grown in the watershed according to annual land use surveys. No conservation practices were simulated. The simulation was run with 3 
results. All input layers were processed using ArcGIS (see Lohani et al. [2020] for further information). Criteria for the four classes of soil runoff potential are detailed in table 3 . The SVI also has a component for leaching; however, that was not relevant for comparison with AnnAGNPS as nutrients are not transported through leaching in the model. In this study we were only comparing the SVI runoff results to sediment yield, which is mostly influenced by runoff.

Historical Land Use Analysis. Detailed land use records are available for GC beginning in 1937 and for BL starting in 1995. These records were used to assess any land that was taken out of cultivation and to evaluate the SVI score for the field-polygons. In order to assign each polygon a SVI score, the zonal statistics by table function was utilized in ArcGIS 10.4 to determine the majority SVI score from the SVI raster grids within each cultivated field polygon. For GC this analysis was done in 1937, 1982, 1996, and 2004. For BL this analysis was done in 1995 , 2003, and 2005. In addition, aerial images were assessed for land removed from cultivation and land identified as "high" in the SVI classification to assess visual indicators of land degradation from surface runoff.

Comparison of SVI and AnnAGNPS. To directly compare the SVI and AnnAGNPS results, the SVI was re-run for the spatially defined AnnAGNPS cells utilizing the same soils and slope input data that the AnnAGNPS model used to calculate output loads. AnnAGNPS was also run considering a static $\mathrm{K}$-factor value to ensure that the model and the SVI were both using the same soil information in their respective assessments. Annual average AnnAGNPS-predicted sediment yield results were classified into four risk classes defined by the edge-of-field soil loss thresholds used in the development of SVI for runoff: (1) low risk for soil loss less than $4.48 \mathrm{t} \mathrm{ha}^{-1}$, (2) moderate for soil loss between 4.5 and $11.2 \mathrm{t} \mathrm{ha}^{-1}$, (3) moderately high for soil loss between 11.2 and $17.9 \mathrm{t}$ $\mathrm{ha}^{-1}$, and (4) high for soil loss greater than $17.9 \mathrm{t} \mathrm{ha}^{-1}$ (Thompson et al. 2020). The SVIsoil loss results were directly compared to the AnnAGNPS sediment yield in a contingency table to identify where the two tools agreed and disagreed. The average AnnAGNPSpredicted sediment yield was calculated for each SVI category, and these results were compared for statistical significance using a two-sided $t$-test with unequal variance.

Table 2

AnnAGNPS-related information for Beasley Lake (BL) and Goodwin Creek (GC) watershed simulations.

\begin{tabular}{lll}
\hline Model inputs & BL watershed & GC watershed \\
\hline Years of simulation & 44 & 21 \\
Number of validation years & 3 & 9 \\
Number of weather stations & 1 & 17 \\
Average cell size (ha) & 0.75 & 0.94 \\
Number of cells & 854 & 2,271
\end{tabular}

Table 3

Criteria for four classes of soil runoff potential (USDA NRCS 2012).

\begin{tabular}{|c|c|c|c|c|}
\hline \multirow[b]{2}{*}{ Soil runoff potential } & \multicolumn{4}{|c|}{ Hydrologic soil group* } \\
\hline & A & B & C & D \\
\hline Low & All area & Slope $†<4$ & Slope $<2$ & $\begin{array}{l}\text { Slope }<2 \\
\text { K-factor } \neq<0.28\end{array}$ \\
\hline Moderate & None & $\begin{array}{l}4 \leq \text { slope } \leq 6 \\
\text { K-factor }<0.32\end{array}$ & $\begin{array}{l}2 \leq \text { slope } \leq 6 \\
\text { K-factor }<0.28\end{array}$ & $\begin{array}{l}\text { Slope }<2 \\
\text { K-factor } \geq 0.28\end{array}$ \\
\hline Moderately high & None & $\begin{array}{l}4 \leq \text { slope } \leq 6 \\
\text { K-factor } \geq 0.32\end{array}$ & $\begin{array}{l}2 \leq \text { slope } \leq 6 \\
\text { K-factor } \geq 0.28\end{array}$ & $2 \leq$ slope $\leq 4$ \\
\hline High & None & Slope $>6$ & Slope $>6$ & Slope $>4$ \\
\hline
\end{tabular}

*Hydrologic soil groups are classified as follows: Group A = sand, loamy sand, or sandy loam soils that have low runoff potential and high infiltration rates even when thoroughly wetted. Group $B=$ silt loam or loam soils that have moderate infiltration rates when thoroughly wetted. Group C = sandy clay loam soils that have low infiltration rates when thoroughly wetted. Group D = clay loam, silty clay loam, sandy clay, silty clay, or clay soils that have very low infiltration rates when thoroughly wetted.

†Slope values are measured as percentage.

$\ddagger \mathrm{K}$-factor refers to the soil erodibility factor $(\mathrm{K})$ found in the USLE. It is a relative index of susceptibility of bare, cultivated soil to particle detachment and transport by rainfall. It is determined by the composition of the soil, saturated hydraulic conductivity, and soil structure.

\section{Results and Discussion}

SVIAnalysis using LiDAR Digital Elevation Models. In the GC watershed, approximately $59 \%$ of cropland was identified as moderate, $11 \%$ as moderately high, and $23 \%$ as high soil loss potential. A visual analysis demonstrated that the upland portions of the watershed had higher SVI scores and the riparian zones bordering the main drainage pathway through the watershed had low or moderate soil loss potential SVI scores (figure 2). Approximately $73 \%$ of $\mathrm{BL}$ cropland was identified as low to moderate soil loss potential with the SVI. Of the remaining $27 \%$ of land, 22\% was moderately high and only $5 \%$ was identified as high soil loss potential. A quick visual analysis of these SVI results indicated that the majority of land identified as high soil loss potential is located in drainage pathways and known ditches within the watershed, or areas that have a distinctly steep slope. As both watersheds consist of soils with high soil erodibility values $(\mathrm{K}>$ 0.32 ) and low infiltration capacity (hydro- logic soil group C and D soils), slope is the defining characteristic that identifies the GC watershed as high risk for soil loss and the BL watershed as predominantly low risk.

With slope as a critical factor for identifying high risk areas, source and resolution of topographic data used with the SVI runoff component are important considerations for future applications. In this study, high resolution DEM data derived from LiDAR were available. However, LiDAR-based DEMs may not be available in some areas where this tool will be utilized. This is an important factor to consider when determining the suitability of this tool for new areas. Chan et al. (2016) explored the discrepancies caused by the resolution of the slope map by utilizing SSURGO slopes compared to those derived from $10 \mathrm{~m}$ DEMs (2016). Their conclusion was that SSURGO slopes were too coarse to target areas with the SVI, but the $10 \mathrm{~m}$ resolution DEM was suitable for watershed-scale applications (Lohani et al. 2020). Other studies have also found that 


\section{Figure 2}

Soil Vulnerability Index (SVI) runoff potential results using LiDAR digital elevation model (DEM) for Goodwin Creek (GC; top) and Beasley Lake (BL; bottom) watersheds. Results are shown for historically cultivated land use only. Boxes in each watershed indicate areas examined further in figures $4(\mathrm{GC})$ and $5(\mathrm{BL})$.

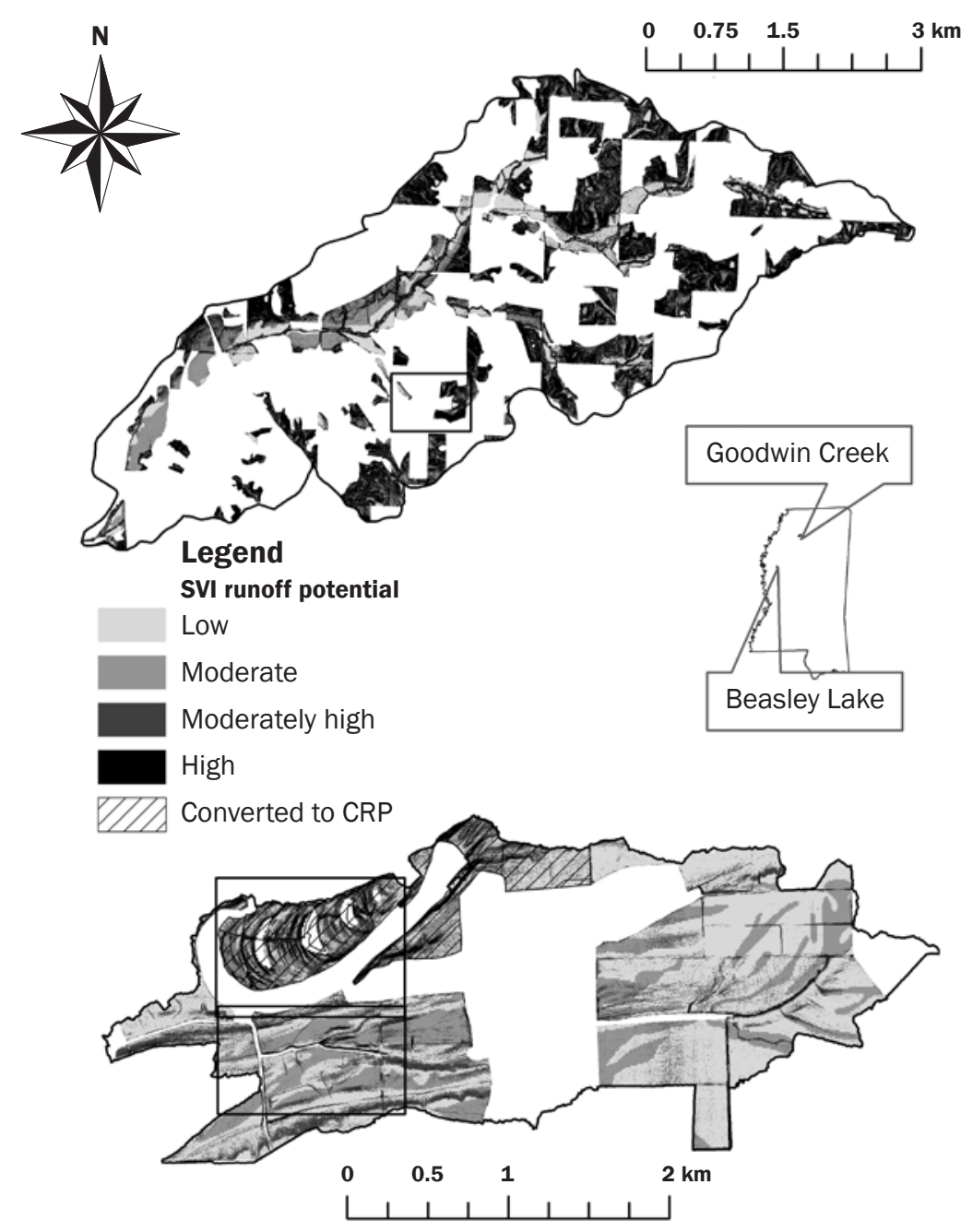

Land use in the BL watershed has also changed over the study period with 85 ha of cultivated land converted to CRP and 9.65 ha of cultivated land converted to vegetated buffers. Of the total 95 ha converted land, 70 ha was ranked as moderately high by the SVI. Figures 2 and 5 demonstrate that most of the high and moderately high classified land is located in the area north of the lake and was converted to CRP, or within drainage pathways, where slope is high. In general, evaluation of land use conversion and aerial images in both GC and BL watersheds indicated that the SVI runoff score was a good predictor of land removed from cultivation or degraded agricultural land.

SVI and AnnAGNPS Comparison. When the SVI was reassessed for AnnAGNPS polygons, in the GC watershed the SVI identified $83 \%$ of the agricultural land as high vulnerability, while the AnnAGNPS-estimated sediment yield identified $61 \%$ of the agricultural land as high and 29\% as moderately high. The estimated sediment yield from the cells identified as low or moderate by the SVI were not statistically different ( $p=$ $0.10)$. However, the sediment yield estimated in the cells in the moderately high and high categories were statistically different $(p \leq$ 0.001). The SVI underpredicted soil vulnerability in the BL watershed compared to the AnnAGNPS-predicted sediment yield. The SVI classification system for AnnAGNPS cells identified $69 \%$ of BL agricultural land as low vulnerability, but the estimated sediment-yield found $47 \%$ of land in the low category and $47 \%$ in the moderate category (table 4). The AnnAGNPS-estimated sediment yield from cells identified as SVI category of low, moderate, or moderately high were not statistically different (single factor ANOVA; $p=0.37$ ). Only land classified as high by the SVI demonstrated AnnAGNPS-predicted sediment yield that was statistically different from the other three categories $(p<0.0001)$.

Contingency tables (tables 5 and 6) show the degree of agreement between the SVI runoff score and the AnnAGNPS-predicted sediment yield categories. In the GC watershed, the highest agreement was the high category with an agreement of $60 \%$ of land; the highest misclassification was land identified as high by the SVI but moderately high by the AnnAGNPS sediment yield. If the moderately high and high categories are combined, then the SVI and AnnAGNPS- cropland was categorized as high in the SV classification system. By 2004, cultivated only 9\%. This decrease from 1937 to 2 corresponds to 458 ha of high SVI-risk cropland removed from cultivation. By 2004, 84\% of the remaining cropland was classified as either low or moderate by the SVI (figure $3)$. This decrease in cropland area identified as high risk is a potential indicator that this land was indeed prone to degradation. Aerial images from some of these areas confirm that the land was subject to gullying and rill erosion (identified by an asterisk in figure 4), and thus a likely contributor of nutrient and sediment runoff. 


\section{Figure 3}

Area of cropland within each Soil Vulnerability Index (SVI) category in the Goodwin Creek watershed in 1937, 1982, 1996, and 2004. In 1937 to 1982 the majority of cropland was in the SVI "high" category, but through time this land was removed from cultivation.

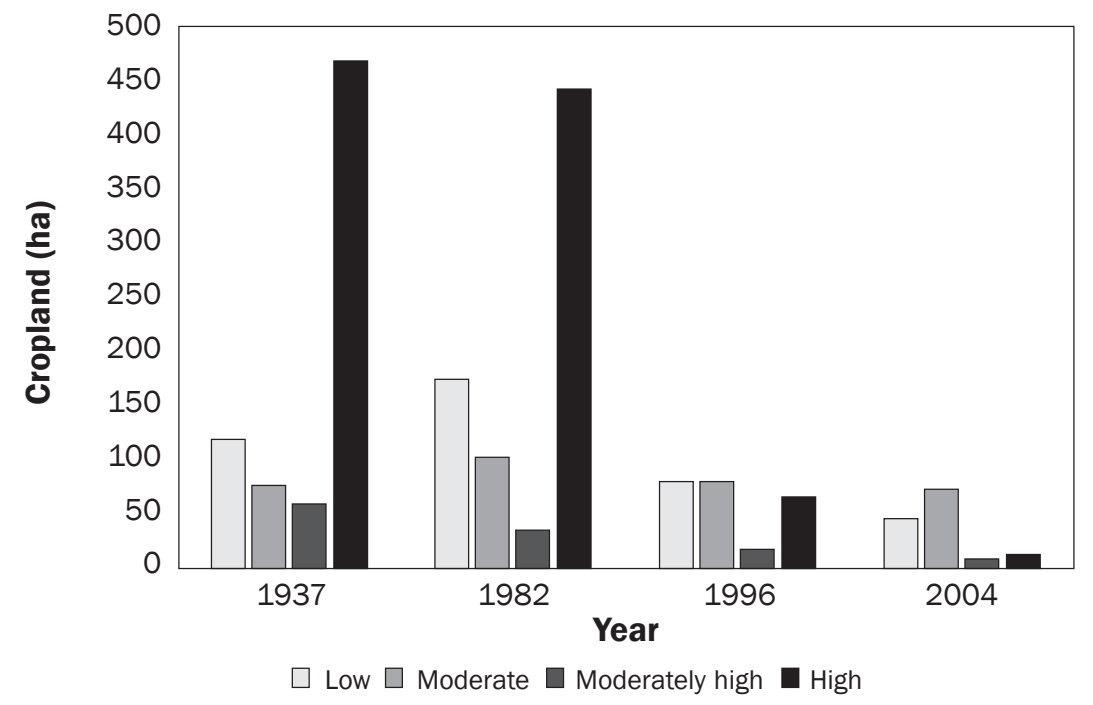

yield agree for $90 \%$ of the GC watershed. In the $\mathrm{BL}$ watershed, the highest agreement was in the low category with $35 \%$ of land in agreement; the highest misclassification $(33 \%)$ was land identified as low by the SVI, but with sediment yield values corresponding to the moderate category. If the low and moderate categories are combined, then the SVI and AnnAGNPS yield agree for $75 \%$ of the BL watershed. These results suggest that the SVI may have overpredicted soil runoff risk in the GC watershed with higher slopes and may have underestimated soil runoff risk

Overall, the comparison indicates that two separate uncalibrated tools mostly agree on soil runoff vulnerability with the perspective of sediment yield for the GC watershed, in the BL watershed with lower slopes. while they agree less than half of the time for the BL watershed. It is important to consider that the AnnAGNPS simulations were not calibrated or validated for sediment yield but were validated for runoff. Runoff validation was performed at the field scale in the $\mathrm{BL}$ watershed and at various scales using subwatersheds in the GC watershed. Ideally, SVI results would also be compared to field-based runoff data, if available. Indeed, comparing the results of two different models has disadvantages. When the models disagree, we do not know which one is correct. When the models agree, we assume that this is evidence for correct predictions; however, it is possible that both models are incorrect. It is unrealistic to have field-based runoff data in all locations where a model or index, such as the SVI, will need to be used. However, imagery, land-based knowledge, and land use histories are generally available for most cropped areas in the United States and can be acquired using publicly available data sources, or by communicating directly with producers and landowners. As is shown in this paper, imagery is a particularly valuable source of information to compare with index results.

Goodwin Creek and Beasley Lake Comparison. Both GC and $\mathrm{BL}$ watersheds have high proportions of hydrologic group D soils, which are prone to runoff. Both

\section{Figure 4}

(a) Aerial image from 1979 and (b) image overlaid with the Soil Vulnerability Index (SVI) runoff classification. Areas highlighted in pink are rated high within the SVI classification system, and within many of these areas evidence of erosional gullies and cropland degradation are observed in the aerial image (identified with asterisk [*] to indicate degraded cropland). Location of box within the Goodwin Creek watershed is shown in figure 2.

(a)

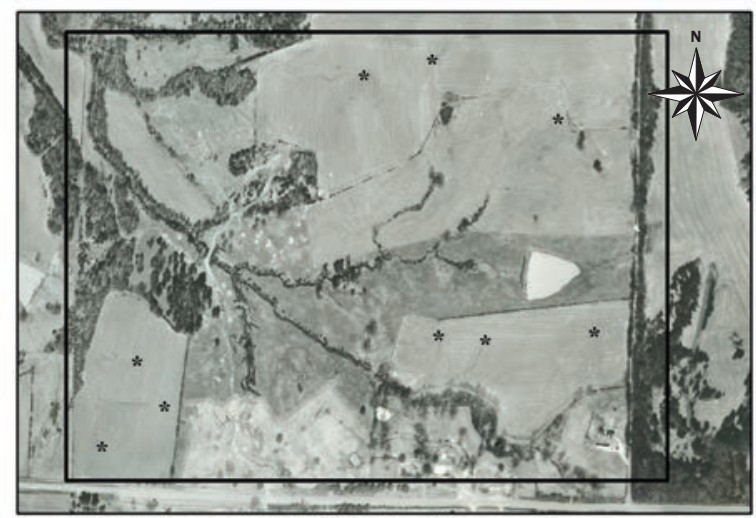

Legend

SVI runoff score

$\begin{array}{ll}\text { Low } & \text { Moderately high } \\ \text { Moderate } & \text { High }\end{array}$ (b)

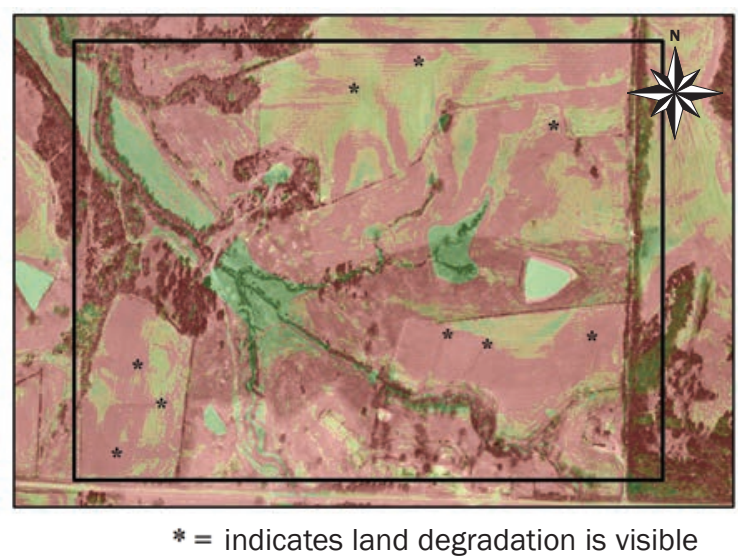




\section{Figure 5}

( $a$ and b) Aerial image from 1992 (c and d) overlaid with Soil Vulnerability Index (SVI) runoff classification for two areas in the Beasley Lake watershed: ( $a$ and $c$ ) north of the lake and ( $b$ and d) south of the lake. Areas highlighted in pink are rated high in the SVI and appear to coincide with many of the drainage pathways within the watershed. Land north of the lake was converted to Conservation Reserve Program in 2003. Location of boxes are shown in figure 2 .

(a)

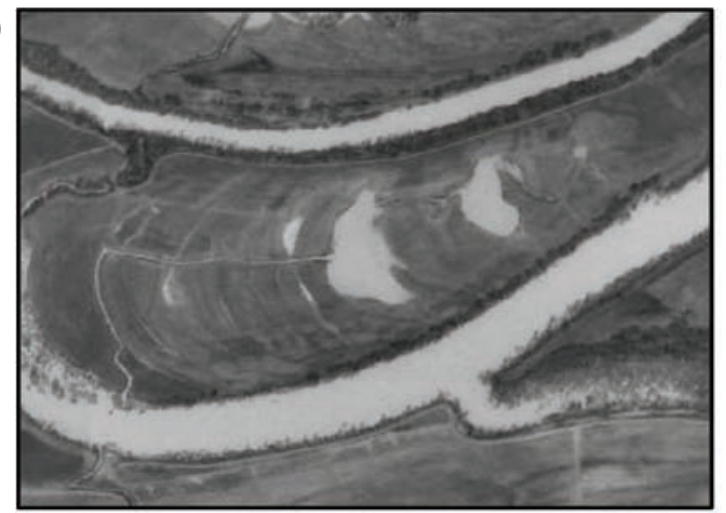

(c)

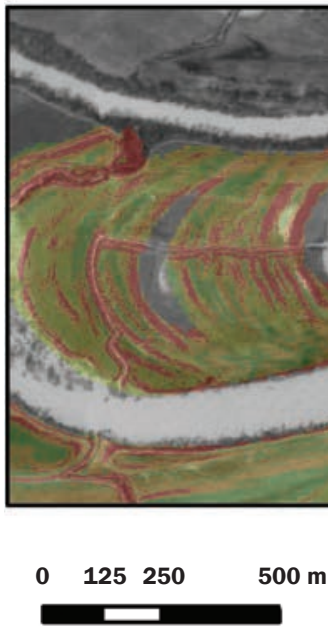

SVI runoff score (b)

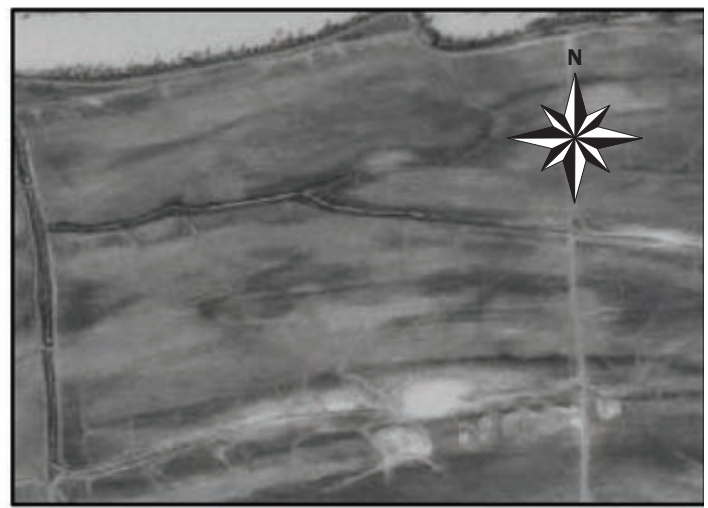

(d)

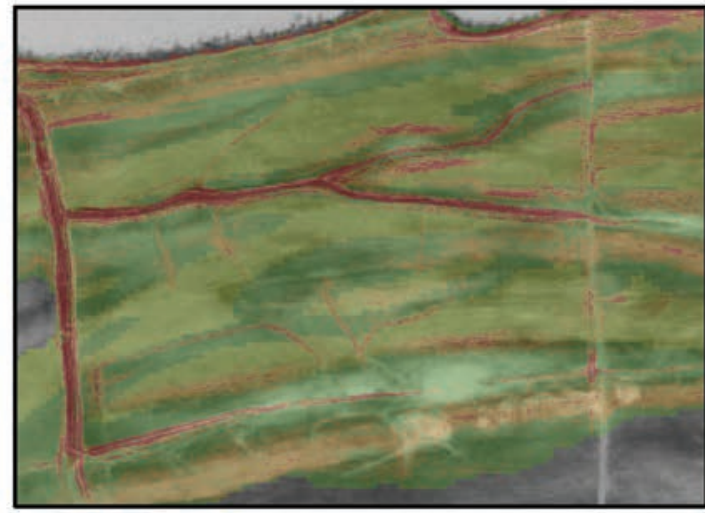

$\mathbf{0}$
Legend

Low

Moderate
Moderately high

High watersheds also have high soil erodibility values; all of GC soils and more than half of BL soils had a K-factor greater than 0.32 . Both watersheds also have similar climate, precipitation patterns, and rainfall intensity. The major variable that differs between $\mathrm{BL}$ and GC watersheds is slope. The BL watershed is relatively flat with $67 \%$ of the watershed in the $0 \%$ to $2 \%$ slope category. On the other hand, the GC watershed has much higher slopes with $51 \%$ of the watershed in the greater than 6\% slope category. BL and GC represent the two extremes in the SVI range of slope threshold. Slope seems to be the most influential factor driving the difference in the runoff component of the SVI classification between the watersheds. Due to high slopes, $83 \%$ of the GC watershed is ranked as high risk. However, only $6.5 \%$ of the $\mathrm{BL}$ watershed is ranked as high, and much of the land ranked as high appears to be in ditches or drainage pathways where there are short lengths of steep slopes (figure 2).These results suggest that SVI runoff results should be used with caution in areas with flat slopes, such as floodplains (Lohani et al. 2020). However, SVI runoff results can be guided when used in combination with a field visit, available imagery, other remotely sensed data, and/or field-based data and expertise. To elaborate, field visits, imagery, and field-based data can provide information on actual conditions of the landscape, as well as land use and management practices that may increase erosional and runoff risks that may not be apparent in the soils databases. By combining multiple sources of data to confirm high risk of soil runoff vulnerability, uncertainty is reduced.

\section{Summary and Conclusions}

Historical analysis of land use in two Mississippi watersheds demonstrates that a high to moderately high SVI score was a good predictor of land that was removed from cultivation, which could be an indicator that this land was prone to degradation. Comparison of the SVI to the AnnAGNPS model demonstrated that the SVI tended to underpredict potential soil loss in the BL watershed, which had flat slopes, and overpredicted potential soil loss in the GC watershed, which had high slopes. In general, the SVI runoff component relied heavily on slope to identify areas of high risk and therefore may underrepresent the risk of erosion and runoff of pollutants in watersheds with flat slopes or watersheds lacking high resolution elevation data. However, 


\section{Table 4}

Beasley Lake watershed and Goodwin Creek watershed areas, areal proportions, and average AnnAGNPS-predicted sediment yield and associated standard deviation for cells within the four classes as defined by the Soil Vulnerability Index (SVI) and by the sediment yield results from AnnAGNPS. Areas are defined by AnnAGNPS cells that consist of predominantly agricultural land use.

\begin{tabular}{|c|c|c|c|c|c|c|}
\hline \multirow[b]{2}{*}{ Classes } & \multicolumn{3}{|c|}{ Goodwin Creek watershed } & \multicolumn{3}{|c|}{ Beasley Lake watershed } \\
\hline & Area (ha) & Proportion (\%) & $\begin{array}{l}\text { Sediment yield } \\
\left(\mathrm{t} \mathrm{ha}^{-1}\right)\end{array}$ & Area (ha) & Proportion (\%) & $\begin{array}{l}\text { Sediment yield } \\
\left(\mathrm{t} \mathrm{ha}^{-1}\right)\end{array}$ \\
\hline Low & 80 & 5.6 & $7.4(2.5)$ & 352 & 69.0 & $5.01(3.7)$ \\
\hline Moderate & 1.1 & 0.07 & $7.5(0.67)$ & 42 & 8.3 & $5.7(4.3)$ \\
\hline Moderately high & 161 & 11 & $13(11)$ & 81 & 16.0 & $5.4(4.3)$ \\
\hline Low & 5.1 & 0.35 & $3.1(1.3)$ & 238 & 47.0 & $2.5(1.1)$ \\
\hline Moderate & 142 & 10 & $8.5(1.9)$ & 238 & 47.0 & $7.2(1.8)$ \\
\hline Moderately high & 410 & 29 & $14.7(1.8)$ & 27 & 5.4 & $14(1.8)$ \\
\hline High & 878 & 61 & $48(48)$ & 5 & 1.0 & $36(27)$ \\
\hline
\end{tabular}

\section{Table 5}

Contingency table for areal percentages in agreement between the Soil Vulnerability Index (SVI) runoff score and the AnnAGNPS-predicted sediment yield for the Goodwin Creek watershed cropland cells (cultivated extent from 1937); the SVI underpredicted $5 \%$ of land area, $60 \%$ was in agreement, and $35 \%$ was overpredicted compared to AnnAGNPS.

\begin{tabular}{lllll}
\hline & \multicolumn{4}{l}{ Sediment yield } \\
\cline { 2 - 5 } SVI runoff & Low & Moderate & $\begin{array}{l}\text { Moderately } \\
\text { high }\end{array}$ & High \\
\hline Low & 0.32 & 5.20 & 0.01 & 0.00 \\
Moderate & 0.00 & 0.07 & 0.00 & 0.00 \\
Moderately high & 0.02 & 3.56 & 6.84 & 0.84 \\
High & 0.01 & 1.01 & 21.7 & 60.4
\end{tabular}

\section{Table 6}

Contingency table for areal percentages in agreement between the Soil Vulnerability Index (SVI) runoff score and the AnnAGNPS-predicted sediment yield for the Beasley Lake watershed cropland cells (cultivated extent from 1996); the SVI underpredicted $39 \%$ of land area, $41 \%$ was in agreement, and $\mathbf{2 0} \%$ was overpredicted compared to AnnAGNPS.

\begin{tabular}{lrlll}
\hline & \multicolumn{3}{l}{ Sediment yield } & Moderately \\
\cline { 2 - 5 } SVI runoff & Low & Moderate & high & 0.06 \\
\hline Low & 35.0 & 33.0 & 0.85 & 0.00 \\
Moderate & 1.5 & 5.6 & 1.30 & 0.29 \\
Moderately high & 7.7 & 4.9 & 3.00 & 0.64 \\
High & 2.2 & 3.4 & 0.25 &
\end{tabular}

in both watersheds much of the watershed area agreed between the SVI and AnnAGNPS results- $45 \%$ in the BL and $68 \%$ in the GC watersheds. Further work comparing the SVI results to field-scale measurements would advance understanding of the tool's suitability in this region. It does seem that the SVI tool, in combina- tion with field-based expertise and analysis of aerial images, would help to more accurately identify areas in need of conservation practice improvements.

\section{Acknowledgements}

We would like to acknowledge numerous members of the USDA Agricultural Research Service (ARS) National
Sedimentation Laboratory who have worked over the years to collect data in Beasley Lake and Goodwin Creek watersheds, especially Darlene Wilcox (data manager, National Sedimentation Laboratory, Oxford, Mississippi) who has developed the geospatial layers for Goodwin Creek. This work was supported by the USDA Natural Resources Conservation Service (NRCS) Conservation Effects Assessment Project (CEAP) Watersheds Assessments and NRCS Soil Science Division.

\section{Disclaimer}

The USDA is an equal opportunity provider and employer. Any use of trade, firm, or product names is for descriptive purposes only and does not imply endorsement by the US Government.

\section{References}

Agnew, L.J., S. Lyon, P. Gérard-Marchant, V.B. Collins, A.J. Lembo,T.S. Steenhuis, and M.T.Walter. 2006. Identifying hydrologically sensitive areas: Bridging the gap between science and application. Journal of Environmental Management 78(1):63-76.

Andrews, S.S., D.L. Karlen, and C.A. Cambardella. 2004. The Soil Management Assessment Framework:A quantitative soil quality evaluation method. Soil Science Society of America Journal 68:1945-1962.

Bagnold, R.A. 1966. An approach to the sediment transport problem from general physics. USGS Professional Paper 422-J. Reston,VA: US Geological Survey.

Bingner, R.L., F.D. Theurer, and Y. Yuan. 2015. AnnAGNPS technical processes. Unpublished Report. Oxford, MS: USDA ARS National Sedimentation Laboratory. http:// www.wcc.nrcs.usda.gov/ftpref/wntsc/H\&H/AGNPS/ downloads/AnnAGNPS_Technical_Documentation.pdf. Bosch, D., F. Theurer, R. Bingner, G. Felton, and I. Chaubey. 1998. Evaluation of the AnnAGNPS water quality model. ASAE Paper No. 98-2195. St. Joseph, MI: American Society of Agricultural Engineers. 
Chan, R., C. Baffaut, A. Thompson, and J. Sadler. 2016 Validating the soil vulnerability index for a claypan watershed. Catena 148:185-194.

Dabney, S.M., F.D. Shields Jr., R.L. Bingner, R.A. Kuhnle, and J.R. Rigby Jr. 2012. Watershed management for erosion and sedimentation control case study: Goodwin Creek, Panola County, MS. In Soil Water and Agronomic Productivity, Advances in Soil Science, eds. R. Lal and B.A. Stewart. Boca Raton, FL: Taylor and Francis.

Douglas-Mankin, K.R., P. Daggupati, A.Y. Sheshukov, and P.L. Barnes. 2013. Paying for sediment: Field-scale conservation practice targeting, funding, and assessment using the Soil and Water Assessment Tool. Journal of Soil and Water Conservation 68(1):41-51, doi:10.2489/ jswc.68.1.41.

Foster, G.R., D.C. Yoder, G.A. Weesies, and T.J. Toy. 2001. The design philosophy behind RUSLE2: Evolution of an empirical model. In Soil Erosion, 95-98. St. Joseph, MI: American Society of Agricultural and Biological Engineers. Gburek, W.J., A.N. Sharpley, L. Heathwaite, and G.J. Folmar. 2000. Phosphorus management at the watershed scale: A modification of the phosphorus index. Journal of Environmental Quality 29(1):130-144.

Hamlett, J.M., D.A. Miller, R.L. Day, G.W. Peterson, G.M. Baumer, and J. Russo. 1992. Statewide GISbased ranking of watersheds for agricultural pollution prevention. Journal of Soil and Water Conservation 47(5):399-404.

Kuhnle, R.A., R.L. Bingner, C.V.Alonso, C.G.Wilson, and A. Simon. 2008. Conservation practice effects on sediment load in the Goodwin Creek Experimental Watershed. Journal of Soil and Water Conservation 63(6):496-503, doi:10.2489/jswc.63.6.496.

Lee, S., A.M. Sadeghi, G.W. McCarty, C. Baffaut, S. Lohani, L.F. Duriancik, A. Thompson, I. Yeo, and C. Wallace. 2018. Assessing the suitability of the Soil Vulnerability Index (SVI) on identifying croplands vulnerable to nitrogen loss using the SWAT model. Catena 167:1-12.

Lizotte, R.E., L.M.W.Yasarer, M.A. Locke, R.L. Bingner, and S.S. Knight. 2017. Lake nutrient responses to integrated conservation practices in an agricultural watershed. Journal of Environmental Quality 46:330-338.

Locke, M.A., S.S. Knight, S. Smith, R.F. Cullum, R.M Zablotowicz, Y. Yuan, and R.L. Bingner. 2008 Environmental quality research in the Beasley Lake watershed, 1995 to 2007: Succession from conventional to conservation practices. Journal of Soil and Water Conservation 63(6):430-442.

Lohani, S., C. Baffaut, A.L.Thompson, N.Aryal, R.L. Bingner, D.L. Bjorneberg, D.D. Bosch, R.B Bryant, A. Buda, S.M. Dabney, A.R. Davis, L.F. Duriancik, D.E. James, K.W. King, P.J.A. Kleinman, M. Locke, G.W. McCarty, L.A. Pease, M.L. Reba, D.R. Smith, M.D. Tomer, T.L. Veith, M.R. Williams, and L.M.W.Yasarer. 2020. Performance of the Soil Vulnerability Index with respect to slope, digital elevation model resolution, and hydrologic soil group. Journal of Soil and Water Conservation 75(1):1227, doi:10.2489/jswc.75.1.12.

Moriasi, D.N., M.W. Gitau, N. Pai, and P. Daggupati. 2015 Hydrologic and water quality models: Performance measures and evaluation criteria. Transactions of the ASABE 58(6):1763-1785.

Niraula, R., L. Kalin, P. Srivastava, and C.J. Anderson. 2013. Identifying critical source areas of nonpoint source pollution with SWAT and GWLF. Ecological Modelling 268:123-133.

NOAA (National Oceanic and Atmospheric Administration). 2017. Global Historical Climate Network Daily for Moorhead, Mississippi. Silver Spring, MD: National Oceanic and Atmospheric Administration. https:// www.ncdc.noaa.gov/cdo-web/datasets/GHCND/ stations/GHCND:USC00226009/detail.

Renard, K.G., G.R. Foster, G.A. Weesies, D.K. McCool, and D.C. Yoder. 1997. Predicting soil erosion by water: A guide to conservation planning with the Revised Universal Soil Loss Equation (RUSLE). USDA Handbook No. 703:404. Washington, DC: USDA Agricultural Research Service.

Soil Survey Staff. USDA NRCS. 2018a. Soil survey geographic database for Panola County, Mississippi. Available online. Washington, DC: USDA Natural Resources Conservation Service.

Soil Survey Staff. 2018b. Soil survey geographic database for Sunflower County, Mississippi. Available online. Washington, DC: USDA Natural Resources Conservation Service.

Theurer, F.D., and C.D. Clarke. 1991. Wash load component for sediment yield modeling. In Proceedings of the 5th Federal Interagency Sedimentation Conference, March 18-21, 1991. Las Vegas, NV: Subcommittee on Sedimentation of the Interagency Advisory Committee on Water Data.

Thompson, A.L., C. Baffaut, S. Lohani, L.F. Duriancik, M.L. Norfleet, and K. Ingram. 2020. Purpose, development, and synthesis of the SoilVulnerability Index for inherent vulnerability classification of cropland soils. Journal of Soil and Water Conservation 75(1):1-11, doi:10.2489/ jswc.75.1.1.

Tim, U.S., S. Mostaghimi, and V.O. Shanholtz. 1992 Identification of critical nonpoint pollution source areas using geographic information systems and water quality modeling. JAWRA Journal of the American Water Resources Association 28(5):877-887.

Tuppad, P., C. Santhi, X. Wang, J.R. Williams, R. Srinivasan, and P.H. Gowda. 2010. Simulation of conservation practices using the APEX model. Applied Engineering in Agriculture 26(5):779-794.

USDA NRCS (Natural Resources Conservation Service). 2012.Assessment of the Effects of Conservation Practices on Cultivated Cropland in the Upper Mississippi River Basin. Washington, DC: USDA Natural Resources Conservation Service.
USDA NRCS. 2017. Soil Climate Analysis Network (SCAN) data for site 2032, Beasley Lake, Mississippi. Washington, DC: USDA Natural Resources Conservation Service. https://wcc.sc.egov.usda.gov/nwcc/site?sitenum=2032. USGS (US Geological Survey). 2010. Mississippi Delta Management Systems Evaluation Areas (MDMSEA). Reston, VA: US Geological Survey. https://www.usgs. gov/centers/lmg-water/science/mississippi-deltamanagement-systems-evaluation-areas-mdmsea?qtscience_center_objects $=0 \# q t-s c i e n c e \_c e n t e r \_o b j e c t s$.

Vaze,J.,J.Teng, and G.Spencer.2010. Impact of DEM accuracy and resolution on topographic indices. Environmental Modelling and Software 25(10):1086-1098.

White, M.J., D.E. Storm, P.R. Busteed, S.H. Stoodley, and S.J. Phillips. 2009. Evaluating nonpoint source critical source area contributions at the watershed scale. Journal of Environmental Quality 38(4):1654-1663.

Wilson, C.G., R.A. Kuhnle, S.M. Dabney, R.N. Lerch, C.H. Huang, K.W. King, and S.J. Livingston. 2014. Fine sediment sources in Conservation Effects Assessment Project watersheds. Journal of Soil and Water Conservation 69(5):402-413, doi:10.2489/ jswc.69.5.402.

Yasarer, L.M.W., R.L. Bingner, and H.G. Momm. 2018 Characterizing ponds in a watershed simulation and evaluating their influence on streamflow in a Mississippi watershed. Hydrological Sciences Journal 63(2):302-311.

Yuan, Y., M.A. Locke, and R.L. Bingner. 2008. Annualized agricultural non-point source model application for Mississippi Delta Beasley Lake watershed conservation practices assessment. Journal of Soil and Water Conservation 63(6):542-551, doi:10.2489/ jswc.63.6.542. 